\title{
Exploration of the propagation of transpovirons within Mimiviridae reveals a unique example of commensalism in the viral world
}

\author{
Sandra Jeudy $\mathbb{D}^{1} \cdot$ Lionel Bertaux $^{1} \cdot$ Jean-Marie Alempic ${ }^{1} \cdot$ Audrey Lartigue $^{1} \cdot$ Matthieu Legendre $\mathbb{D}^{1}$. \\ Lucid Belmudes $^{2}$ - Sébastien Santini ${ }^{1}$ - Nadège Philippe ${ }^{1}$. Laure Beucher ${ }^{2}$ - Emanuele G. Biondi ${ }^{3}$ - Sissel Juul ${ }^{4}$. \\ Daniel J. Turner ${ }^{4} \cdot$ Yohann Couté $_{\left(\mathbb{C}^{2}\right.}^{2} \cdot$ Jean-Michel Claverie ${ }^{1} \cdot$ Chantal Abergel $^{1}{ }^{1}$
}

Received: 9 September 2019 / Revised: 27 November 2019 / Accepted: 28 November 2019 / Published online: 10 December 2019

(c) The Author(s) 2019. This article is published with open access

\begin{abstract}
Acanthamoeba-infecting Mimiviridae are giant viruses with dsDNA genome up to $1.5 \mathrm{Mb}$. They build viral factories in the host cytoplasm in which the nuclear-like virus-encoded functions take place. They are themselves the target of infections by 20-kb-dsDNA virophages, replicating in the giant virus factories and can also be found associated with 7-kb-DNA episomes, dubbed transpovirons. Here we isolated a virophage (Zamilon vitis) and two transpovirons respectively associated to B-and C-clade mimiviruses. We found that the virophage could transfer each transpoviron provided the host viruses were devoid of a resident transpoviron (permissive effect). If not, only the resident transpoviron originally isolated from the corresponding virus was replicated and propagated within the virophage progeny (dominance effect). Although B- and C-clade viruses devoid of transpoviron could replicate each transpoviron, they did it with a lower efficiency across clades, suggesting an ongoing process of adaptive co-evolution. We analysed the proteomes of host viruses and virophage particles in search of proteins involved in this adaptation process. This study also highlights a unique example of intricate commensalism in the viral world, where the transpoviron uses the virophage to propagate and where the Zamilon virophage and the transpoviron depend on the giant virus to replicate, without affecting its infectious cycle.
\end{abstract}

These authors contributed equally: Sandra Jeudy, Lionel Bertaux

Supplementary information The online version of this article (https:// doi.org/10.1038/s41396-019-0565-y) contains supplementary material, which is available to authorized users.

Sandra Jeudy

Sandra.Jeudy@igs.cnrs-mrs.fr

$\square$ Jean-Michel Claverie

Jean-Michel.Claverie@univ-amu.fr

$\square$ Chantal Abergel

Chantal.Abergel@igs.cnrs-mrs.fr

1 Aix-Marseille Université, Centre National de la Recherche Scientifique, Information Génomique \& Structurale, Unité Mixte de Recherche 7256; Institut de Microbiologie de la Méditerranée, FR3479, 13288 Marseille, Cedex 9, France

2 Université Grenoble Alpes, CEA, INSERM, IRIG, BGE, 38000 Grenoble, France

3 Aix-Marseille Université, Centre National de la Recherche Scientifique, Laboratoire de Chimie Bactérienne, Unité Mixte de Recherche 7283; Institut de Microbiologie de la Méditerranée, FR3479, 13009 Marseille, France

4 Oxford Nanopore Technologies Ltd, Oxford Science Park, Oxford, UK

\section{Introduction}

While for decades most of the focus was given to pathogenic viruses and viruses infecting parasites of human, animals and plants for obvious reasons, they are now recognized as major players in the environment and are by far the most abundant entities in all biotopes including oceans, fresh water, soil [1-5] and are even found in association with multicellular organisms' microbiotes [6-8]. They have also received a lot of attention with the discovery of Mimivirus, the first giant virus with icosahedral capsids visible by light microscopy, enclosing a genome of $1.2 \mathrm{Mb}$ and thousand genes [9, 10]. Many members of the Mimiviridae have then been isolated as well as new families such as the proposed Pandoraviridae [11], Molliviridae [12] and Pithoviridae [13], demonstrating that giant viruses now appear ubiquitous in all kinds of environment. Giant viruses infect unicellular eukaryotes, some regulating the populations of bloom forming algae [14-19]. As of today, the Mimiviridae family appears composed of several distinct subfamilies [10, 15-18, 20-24] one of which, the proposed Megamimivirinae [5, 17, 18], corresponds to the family members specifically infecting 
Acanthamoeba [20-23]. Members of this subfamilies, collectively refers to as "mimiviruses" throughout this article, can be infected by dsDNA satellite viruses called virophages only able to replicate using the already installed intracytoplasmic viral factory $[16,25-28]$. This new type of satellite viruses constitute the Lavidaviridae family [29]. In addition to virophages, mimiviruses can be found associated with a linear plasmid-like $7 \mathrm{~kb}$ DNA called a transpoviron $[26,29,30]$ making their mobilome uniquely complex among the known large DNA virus families. Sputnik, the first discovered virophage, was found to infect the A-clade Mamavirus [25]. Since it caused the formation of abnormal, less infectious, Mamavirus ${ }_{\mathrm{A}}$ particles, it was initially proposed that virophages would in general protect host cells undergoing giant viruses' infections. Such a protective role was quantitatively demonstrated for the protozoan Cafeteria roenbergensis, infected by the $\mathrm{CroV}$ [15] virus, in presence of the Mavirus virophage [31, 32]. However, it was later recognized that some virophages replicated without visibly impairing the replication of their associated host virus. This is the case for the mimiviruses of the $\mathrm{B}$ or $\mathrm{C}$ clades when infected by the Zamilon virophage [28]. On the other hand, members of the A-clade appeared non permissive to Zamilon replication [28]. The resistance to Zamilon infection was linked to a specific locus proposed to encode the viral defence system MIMIVIRE [33-35] but the actual mechanisms governing the virulence of a given virophage vis-à-vis its host virus remain to be elucidated [34, 35]. Transpovirons are commonly detected in Mimivirus genomes and might also be involved in the protection of the mimiviruses against the deleterious effects of virophages infection. In this study we took advantage of a newly isolated virophage (Zamilon vitis) and of its ability to propagate different transpovirons to investigate the specificity of the transpoviron/host virus relationship. We also used B- and C-clade strains of mimiviruses originally devoid of transpoviron to investigate the possible role of the transpoviron in the context of virophage co-infections. Finally, we analyzed the proteome of virophage particles replicated on B- and C-clades host viruses, with and without resident transpoviron, to identify transpoviron proteins that could be involved in the coevolution process allowing the transpovirons to be replicated by mimiviruses.

\section{Materials and methods}

\section{Viruses isolation}

The new giant viruses' strains were isolated from soil recovered from a French vineyard $\left(43^{\circ} 20^{\prime} 25^{\prime \prime} \mathrm{N}-5^{\circ} 24^{\prime} 51^{\prime \prime} \mathrm{E}\right.$, $\mathrm{M}_{\mathrm{C}}$. vitis), muddy water collected in the Ross river mangrove near Townsville $\left(19^{\circ} 15^{\prime} 42.39^{\prime \prime} \mathrm{S}, 146^{\circ} 49^{\prime} 5.50^{\prime \prime} \mathrm{E}, \mathrm{M}_{\mathrm{B}}\right.$. australiensis) and water collected from a well nearby Bamako (12 31'28.6”N 751'26.3”' $\mathrm{W}, \mathrm{M}_{\mathrm{B}}$. maliensis).

\section{Virus production}

After being treated with antibiotics the different resuspended samples were added to a culture of Acanthamoeba castellanii (Douglas) Neff (ATCC $30010^{\mathrm{TM}}$ ) cells adapted to Fungizone $(2.5 \mu \mathrm{g} / \mathrm{ml})$ and cultures were monitored for cell death as previously described [11-13, 20]. Each virus was then cloned [12] and the viral clones $\left(M_{B}\right.$. australiensis, $M_{C}$. vitis and $M_{B}$. maliensis) were recovered and amplified prior purification, DNA extraction and cell cycle characterization by electron microscopy (EM). Permissivity to virophage infection on the various giant viruses was analysed using the same protocol to assess the production of virophage after one round of coinfection of each clone with the purified virophage.

\section{Virus purification}

All giant viruses were purified on a $\mathrm{CsCl}$ gradient as follows. The cell lysate was centrifuged $10 \mathrm{~min}$ at $500 \times g$ and the supernatant was centrifuged at $6800 \times g$ for $45 \mathrm{~min}$. The viral pellet was washed once with K36 buffer and the viruses were resuspended in $\mathrm{CsCl} 1.2$ density, loaded on a gradual $\mathrm{CsCl}$ gradient of 1.3/1.4/1.5 densities and centrifuged at $100,000 \times g$ for $20 \mathrm{~h}$. The viral disk was then washed three times with K36 buffer. In contrast to Sputnik virophage, $Z$. vitis and our various giant viruses were still infectious after treatment at $65^{\circ} \mathrm{C}$. We thus could not apply the previously published protocol [26] to separate Z. vitis from the giant viruses. Instead we used several steps of filtration/centrifugation with a final purification on sucrose gradient. The preparation was filtered on $0.2 \mu \mathrm{m}$ filter and centrifuged at $100,000 \times g$ for $90 \mathrm{~min}$. The pellet was resuspended in $5 \mathrm{ml}$ of $40 \mathrm{mM}$ Tris $\mathrm{HCl} \mathrm{pH} 7.5$ and filtered on $0.1 \mu \mathrm{m}$ filter. The filtrate was then centrifuged at $150,000 \times \mathrm{g}$ for $1 \mathrm{~h}$, and the pellet resuspended in $0.2 \mathrm{ml}$ of $40 \mathrm{mM}$ Tris $\mathrm{HCl} \mathrm{pH} 7.5$ and loaded on a $70 \% / 60 \% / 50 \% /$ $40 \%$ sucrose gradient and centrifuged at $200,000 \times$ g for 24 $\mathrm{h}$. The band corresponding to the virus was recovered with a syringe and washed once with $40 \mathrm{mM}$ Tris $\mathrm{HCl} \mathrm{pH} \mathrm{7.5.} \mathrm{The}$ purification was controlled by negative staining observation using a FEI Tecnai G2 operating at $200 \mathrm{kV}$ (Fig. S1). Competition experiments were performed using a large excess of virophage particles compared with the giant virus $\left(10^{3}\right.$ for 1$)$.

\section{Synchronous infections for TEM observations of the infectious cycles}

A. castellanii adherent cells in $20 \mathrm{ml}$ culture medium were infected with each giant virus with a MOI of 50 for 
synchronization. After $1 \mathrm{~h}$ of infection at $32^{\circ} \mathrm{C}$, cells were washed three times with $30 \mathrm{ml}$ of PPYG to eliminate the excess of viruses. For each infection time (every hour from 1 to $11 \mathrm{~h}$ post infection (pi)), $2.5 \mathrm{ml}$ were recovered and we did include them in resin using the osmium-thiocarbohydrazideosmium method [36]. Ultrathin sections of $90 \mathrm{~nm}$ were observed using a FEI Tecnai G2 operating at $200 \mathrm{kV}$.

\section{DNA extraction for sequencing}

For the $\mathrm{M}_{\mathrm{C}}$. vitis clone still associated with the Zamilon vitis virophage we did not try to exhaustively separate the giant virions from $Z$. vitis virions prior to DNA extraction. For each giant virus clone, genomic DNA was extracted from $10^{10}$ virus using the PureLink ${ }^{\mathrm{TM}}$ Genomic DNA mini kit (Invitrogen) according to the manufacturer's protocol. Finally, for the virophage, after its separation from the giant virus, the DNA was extracted using the same protocol. The purified DNAs were loaded on an agarose gel in search of an extra DNA band suggestive of the presence of an episome that could correspond to a transpoviron. Sequencing of $\mathrm{M}_{\mathrm{C}}$. vitis and Moumouvirus ${ }_{\mathrm{B}}$ australiensis was performed using Illumina technology on an Illumina MiSeq and the Moumouvirus ${ }_{B}$ australiensis transpoviron (matv) sequence transpoviron DNA was extracted and purified from an agarose gel and sent to Nanopore for sequencing. The $\mathrm{M}_{\mathrm{B}}$. maliensis purified DNA was sent to the Novogene company for library preparation and Illumina PE150 sequencing. Moumou$\operatorname{virus}_{B}$ australiensis genome was sequenced using the Pacbio technology.

\section{Genome sequencing, assembly and annotation}

\section{Library preparation for Nanopore technology}

DNA was quantified using a Qubit 3.0 Fluorimeter (Thermo Fisher Scientific, MA, USA) following the manufacturer's protocol, and was found to be $12.7 \mathrm{ng} \cdot \mathrm{ml}^{-1} .7 .5 \mu \mathrm{l}$ of this DNA was used for library preparation using the RAD002 kit (Oxford Nanopore Technologies, Oxford, UK). Since the input quantity of DNA was lower than recommended for this kit, the active FRM reagent was diluted with three volumes of heat-inactivated FRM, to avoid over-fragmentation of the DNA. The library preparation reaction was set up as follows: the reaction (DNA $7.5 \mu \mathrm{l}, 0.25 \times \mathrm{FRM} 2.5 \mu \mathrm{l}$ ) was incubated for $1 \mathrm{~min}$ at $30^{\circ} \mathrm{C}$ followed by $1 \mathrm{~min}$ at $75^{\circ} \mathrm{C}$. We added 1 $\mathrm{ml}$ of RAD reagent from the RAD002 kit and $0.2 \mathrm{ml}$ of Blunt TA ligase (New England Biolabs, MA, USA) and the reaction was incubated for $5 \mathrm{~min}$ at room temperature. The prepared library was then loaded onto a FLO-MIN106 flowcell (version 9.4 nanopores) as per Oxford Nanopore Technologies' standard protocol.

\section{Library preparation for Illumina technology}

Genome sequencing was performed using the instrument Illumina MiSeq. Libraries of genomic DNA were prepared using the Nextera DNA Library Preparation Kit as recommended by the manufacturer (Illumina). The sequencing reaction was performed using the MiSeq Reagent Kit v2 (300-cycles), paired-end reads of $150 \mathrm{nt} \times 2$ (Illumina).

The assembly of Moumouvirus ${ }_{B}$ australiensis genome sequence was performed on one SMRT cell of Pacbio data using the HGAP workflow [37] from the SMRT analysis framework version 2.3.0 with default parameters, resulting in 84,565 corrected reads.

The MinION library was sequenced for $1 \mathrm{~h}$ on a MinION Mk1B flowcell (Oxford Nanopore Technologies), generating $\sim 220 \mathrm{Mb}$ of sequence data. Basecalling was performed using the 1D Basecalling for FLO-MIN106 450 bps r1.121 [workflow ID: 1200] workflow (Oxford Nanopore Technologies), and yielded 128,623 reads with a mean length of 1701 bases. Data were filtered to remove reads with a quality score below 8 , leaving 76,936 reads, and a mean length of 2369 bases. The reads were assembled using Canu with the default parameters, but with the option stopOnReadQuality $=$ false. The matv resulting from this assembly was further polished using the $\mathrm{M}_{\mathrm{B}}$. australiensis Pacbio error corrected reads.

The assembly of the Megavirus ${ }_{C}$ vitis, Zamilon vitis and Megavirus vitis transpoviron (mvtv) genomes was performed using Spades (version 3.9.0) [38] on MiSeq Illumina paired-end reads and Pacbio long reads when available. Spades was used with the following parameters: careful, $k=17,27,37,47,57,67,77,87,97,107,117$, 127 , cov-cutoff $=$ off and Pacbio option. For Moumouvir$\mathrm{us}_{\mathrm{B}}$ maliensis, for which long reads were not available, the assembly was performed using Illumina paired-end reads and Spades (version 3.12.0) with the following parameters: careful, no reads correction, $k=33,55,77,99,127$.

Gene annotation of genomic sequences was done using Augustus [39] trained on already published members of the subfamily gene sets. The tRNAs were searched using tRNAscan-SE [40] with default parameters. Functional annotation of predicted protein-coding genes was done using homology-based sequence searches (BlastP against the NR database [41] and search for conserved domains using the Batch CD-Search tool [42]).

\section{Phylogenetic analyses}

The phylogenetic tree of the transpovirons (Fig. 2) was computed using a concatenation of the three conserved genes (orthologous to mvtv_2, mvtv_6 and mvtv_7, see Fig. 2) using the optimal model "LG+G" selected by Prottest [43]. The phylogeny of the giant viruses 
(including Megavirus $_{\mathrm{C}}$ vitis, Moumouvirus $\mathrm{B}_{\mathrm{B}}$ australiensis and Moumouvirus $s_{B}$ maliensis, Fig. S2) was performed on a concatenation of the single copy genes shared by all mimiviruses. For that we first predicted the genes using CompareM (https://github.com/dparks1134/CompareM) and clustered them with MCL [44], resulting in 367 conserved genes, and selected among them the 197 present in exactly one copy per virus. Next, the sequences were aligned using Mcoffee [45] and concatenated. Finally, the phylogenetic tree produced from the resulting superalignment was based on the optimal "VT" model selected by Prottest [43]. Average nucleotide identity between the different strains (Fig. S2) was calculated using the OAU tool [46].

\section{MS-based proteomic analyses}

\section{Characterization of virion proteomes by data dependent acquisition}

For proteomic analysis the virions pellets were resuspended

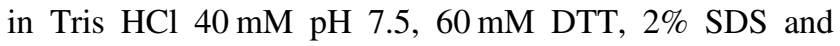
incubated $10 \mathrm{~min}$ at $95{ }^{\circ} \mathrm{C}$. The protein concentration of the lysates were measured using the $660 \mathrm{~nm}$ Protein Assay Reagent appended with Ionic Detergent Compatibility Reagent (Thermo Scientific) and $4 \mu \mathrm{g}$ of proteins were analyzed as previously described [12]. Two replicates were analyzed per sample, except for $Z$. vitis purified from $M_{B}$. maliensis and $Z$. vitis purified from $M_{C}$. chilensis containing matv. Peptides and proteins were identified and quantified using MaxQuant software (version1.6.2.10) [47]. Spectra were searched against the corresponding Megavirus $_{C}$ chilensis, Megavirus $_{C}$ vitis, Moumouvirus ${ }_{B}$ australiensis, Moumouvirus $_{\mathrm{B}}$ maliensis, Zamilon vitis, mvtv, matv and Acanthamoeba castellanii protein sequence databases and the frequently observed contaminants database embedded in MaxQuant. Minimum peptide length was set to 7 aa. Maximum false discovery rates were set to 0.01 at PSM, peptide and protein levels. Intensity-based absolute quantification (iBAQ) [48] values were calculated from MS intensities of unique + razor peptides. Proteins identified in the reverse and potential contaminants databases as well as proteins only identified by site were discarded from the final list of identified proteins. For each analysis, iBAQ values were normalized by the sum of $\mathrm{BBAQ}$ values in the analyzed sample [49]. Only proteins identified with a minimum of two unique + razor peptides in one sample were considered.

\section{Dominance effect validation by PCR}

Cells were grown in T75 flasks and infected either with $M_{B}$. australiensis (carrying matv) at MOI 10 and a large excess $\left(10^{3}\right.$ for 1 giant virus particle) of virophage carrying mvtv, or with $\mathrm{M}_{\mathrm{C}}$. vitis (carrying mvtv) at MOI 10 and a large excess of virophage carrying matv. After $40 \mathrm{~min}$ of infection, the cells were washed three times and distributed in 12-well plates (1 ml per well). Cells were collected from a well at $45 \mathrm{~min}, 2 \mathrm{~h}, 4 \mathrm{~h}, 6 \mathrm{~h}, 8 \mathrm{~h}$ and $24 \mathrm{~h}$ pi. The cells were centrifuged at $1000 \times g$ for $3 \mathrm{~min}$, except for the last point at $24 \mathrm{~h}$ that was centrifuged at $16,000 \times g$ for $10 \mathrm{~min}$. Each pellet was resuspended in $100 \mu$ of PPYG medium and cells were frozen in liquid nitrogen to stop the infection and stored at $-80^{\circ} \mathrm{C}$. PCR were performed using the Terra PCR Direct Polymerase Mix (Clontech) directly on the cell lysates using the following primers:

qPCR-matv_F TCGCTCATTGATTCACTTTGTAC; qPCR-matv_R AATGTATTATGGGCGAATAATGTT; PCR produced an amplicon of $185 \mathrm{bp}$.

qPCR-mvtv_F GGCATAAGCAGGTTCGAAAT, qPCRmvtv_R CATGGCGTGATATTGGTGTG; PCR produced an amplicon of $194 \mathrm{bp}$.

The PCR experiments were stopped after 20 cycles of amplification and $7 \mu \mathrm{l}$ of the reaction products were deposited on agarose gel (Fig. S3).

\section{Competition experiments}

Cells were grown in T25 flasks ( $5 \mathrm{ml}$ growth medium) and infected with host viruses carrying one transpoviron at MOI 0.25 and a large excess ( $10^{3}$ for 1 giant virus particle) of virophage carrying the complementary transpoviron. After cell lysis, $100 \mu \mathrm{l}$ of the culture medium containing virophage and host viruses were used to infect another T25 flask containing adherent fresh cells. This process was repeated ten times.

\section{Selective identification of transpoviron in virions capsids}

To distinguish the mvtv and matv transpovirons, two sets of primers were designed:

$\operatorname{mvtvP}_{\text {Fwd }}$ : ACCTTCTTGTGCCTTTACTGC, mvtvP $\mathrm{Pev}_{\mathrm{Re}}$ : CAGGGTTCGGACGGATTACT; PCR produced a $939 \mathrm{bp}$ amplicon.

matvP $P_{\text {Fwd }}$ : TCGCTCATTGATTCACTTTGTAC, matv$\mathrm{P}_{\text {Rev }}$ : CAAAGGGGAGGAAATAATGGAGA; PCR produced a 263 bp amplicon.

PCR were performed using the Terra PCR Direct Polymerase Mix (Clontech) directly on the cell lysates after each round of co-infection. To check the stability of the transpovirons over time, up to ten additional rounds of virus production were performed and the presence of the transpoviron was assessed by PCR.

Total DNA was extracted from purified host viruses and virophages using the PureLink Genomic DNA Mini Kit (Thermo Fisher Scientific) and serial dilutions of DNA were 
performed and deposited on a $0.8 \%$ agarose gel ran for $45 \mathrm{~min}$ at $100 \mathrm{~V}$. For host viruses, we deposited from 1 to $0.25 \mu \mathrm{g}$ of total DNA and for virophages, from $1 \mu \mathrm{g}$ to $62.5 \mathrm{ng}$ DNA. DNA bands were revealed using BET staining and images were recorded on a Chemi-smart 2000WL-20M camera (Fischer Bioblock Scientific).

\section{Results}

\section{Megavirus $_{C}$ vitis, Moumouvirus ${ }_{B}$ australiensis, Moumouvirus $_{B}$ maliensis and their mobilomes}

Three samples recovered from various locations (France, Australia and Mali) produced lytic infections phenotypes when added to cultures of Acanthamoeba castellanii cells. Viral factories were recognizable in the amoeba cells after DAPI staining and we observed the accumulation of spherical particles visible by light microscopy in the culture medium (Fig. 1a). The corresponding virus populations were cloned and amplified as previously described [12]. In all cases, negative staining EM images confirmed the presence of icosahedral virions of $\sim 450 \mathrm{~nm}$ in diameter with a stargate structure at one vertex, as was observed previously for all members of the Mimiviridae infecting Acanthamoeba cells $[20,28,50,51]$. For some clones of the giant virus isolated from the French sample, associated icosahedral virions of $\sim 70 \mathrm{~nm}$ diameter were also visible, suggesting the presence of virophages (Fig. 1b-f).

Based on its genome sequence, this new isolate was determined to belong to the $\mathrm{C}$ clade and named Megavirus ${ }_{\mathrm{C}}$ vitis (Fig. S2). Its associated virophage was named Zamilon vitis, in reference to its genomic similarity with the original Zamilon virophage [28]. In addition, the genome sequence assembly process revealed the presence of a $7 \mathrm{~kb}$ dsDNA sequence homologous to previously described transpovirons [26]. The Megavirus ${ }_{C}$ vitis associated transpoviron was named mvtv. The Australian isolate was found to be a member of Mimiviridae clade B, and was named Moumouvirus $_{B}$ australiensis (Fig. S2). It came with its own transpoviron that we named matv. Finally, the Bamako (Mali) isolate was determined to be another B-clade member, and named Moumouvirus ${ }_{B}$ maliensis (Fig. S2). This last virus was devoid of transpoviron.

For this study, we included the previously isolated Megavirus $_{C}$ chilensis, as a member of Mimiviridae clade C,

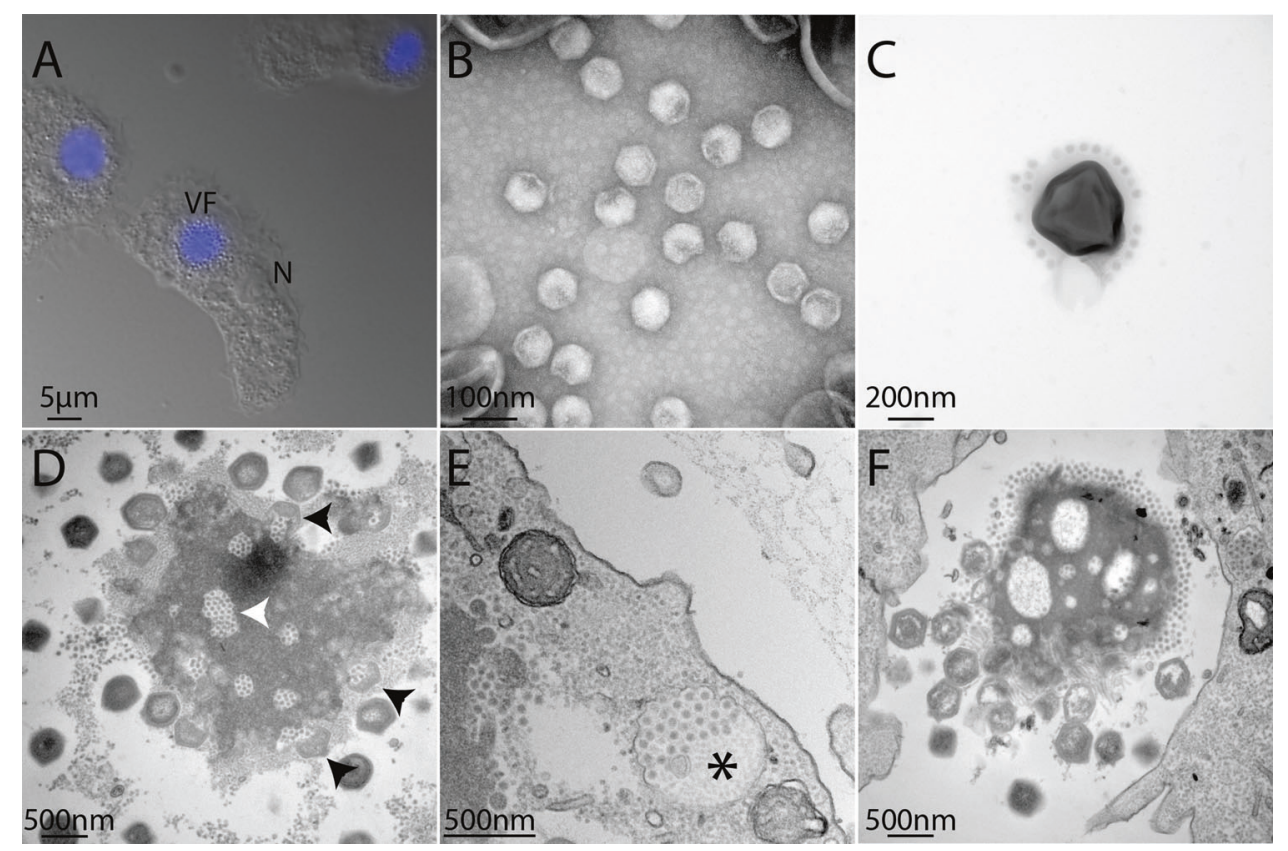

Fig. 1 Microscopy images of Megavirus $_{C}$ vitis and its associated virophage $\mathbf{Z}$. vitis. a Fluorescence image of DAPI-stained A. castellanii cells infected by $\mathrm{M}_{\mathrm{C}}$. vitis and its virophage. Viral particles are visible in the periphery of the viral factory (VF). The cell nucleus $(\mathrm{N})$ remains visible but its fluorescence becomes undetectable due to the intense labelling of the VF DNA. b Transmission electron microscopy (TEM) of Zamilon vitis particles observed by negative staining electron microscopy; c TEM of virophage particles stuck to the giant virus particle (negative staining); $\mathbf{d}$ ultrathin section TEM of a $\mathrm{M}_{\mathrm{C}}$. vitis viral factory observed in late infection of $A$. castellanii cells: virophage particles can be seen in holes in the VF (white arrowhead) as well as penetrating a maturing $\mathrm{M}_{\mathrm{C}}$. vitis particle (black arrowheads); e neosynthesized Z. vitis virophage particles gathered in vacuoles (black star) are seen at the periphery of the infected cell suggesting that they are released by exocytosis. f TEM image of an isolated viral factory observed in an ultrathin section of a late infection of $A$. castellanii cells: virophages accumulate at one pole of the $\mathrm{VF}$ as well as in holes in the VF while immature and mature $\mathrm{M}_{\mathrm{C}}$. vitis particles are seen at the opposite pole of the VF (Supplementary movie). 
devoid of transpoviron (Fig. S2). Underscores A, B and C are used throughout this article to indicate the clade origin of the various mimiviruses.

\section{Comparison of Acanthamoeba cells co-infected by B- or C-clade mimiviruses and Z. vitis}

The infectious cycles of $M_{C}$. vitis (Fig. S4), $M_{C}$. chilensis, $\mathrm{M}_{\mathrm{B}}$. australiensis and $\mathrm{M}_{\mathrm{B}}$. maliensis appeared very similar to that of other mimiviruses, with an initial internalization of the virions in vacuoles, followed by the opening of the stargate and the fusion of the internal membrane with that of the vacuole to deliver the nucleoid in the cytoplasm. After 3 $\mathrm{h}$ pi, viral factories develop in the cell cytoplasm, delineated by a mesh of fibres excluding all organelles [20, 52]. Later on, neo-synthesized virions are seen budding and maturing at their periphery. Virophages specifically associated to the mimiviruses are thought to penetrate the cells at the same time as their host viruses, either enclosed in the host virus particles, or sticking to their external glycosylated fibrils (Fig. 1c) [25]. The virophages are devoid of a transcription machinery and thus use the transcription apparatus of the host virus to express their genome once released in the cell cytoplasm [25, 53]. During infection of Acanthamoeba cells with $\mathrm{M}_{C}$. vitis or $\mathrm{M}_{C}$. chilensis in the presence of $Z$. vitis, regions depleted of electron dense material ("holes") appeared in the viral factory prior to the assembly of any virion. $Z$. vitis virophage particles then start to accumulate inside these holes (Figs. 1, S5C, D, Supplementary movie) as early as $4 \mathrm{~h} \mathrm{pi}$, before the production of host virus particles. Such infectious cycle is reminiscent of the one described for the association between virophage (Sputnik and Zamilon) and mimiviruses [25, 26, 28], with virophages visible at the periphery of the viral factory, some of them seemingly penetrating inside the maturing giant virions (Fig. 1d). The infectious cycle of Moumouvirus ${ }_{B}$ australiensis during co-infection of Acanthamoeba with the $\mathrm{Z}$. vitis virophage was very similar to the one of $\mathrm{M}_{\mathrm{C}}$. vitis except that instead of holes, the viral factory appeared to segregate the production of virophages in a separate compartment (Fig. S5E, F). In all cases, during the latest stage, virophages were seen in large vacuoles that appeared to migrate toward the cell membrane to be released through exocytosis (Fig. 1e). However, while Sputnik co-infections lead to aberrant and non-infectious Mimivirus particles $[25,26], Z$. vitis, as other Zamilon virophages, does not visibly impede the replication of its host viruses, abnormal particles of which were never observed [28].

\section{The newly isolated mimiviruses' genomes}

The dsDNA genome sequence of Megavirus ${ }_{C}$ vitis was assembled into a single contig of $1,242,360$ bp with a $\mathrm{G}+\mathrm{C}$ content of 25\%. It was very close to Megavirus Terra1 [54] and to the C-clade prototype Megavirus ${ }_{C}$ chilensis [20] with whom it shared 99.1 and $96.9 \%$ identical nucleotides over the entire genome length, respectively (Fig. S2). Moumouvirus $_{B}$ australiensis genome sequence was assembled in one contig of $1,098,002 \mathrm{bp}(25 \% \mathrm{G}+\mathrm{C})$, and that of Moumouvirus $_{B}$ maliensis in one contig of $999,513 \mathrm{bp}(25 \%$ $\mathrm{G}+\mathrm{C}$ ). As shown in Fig. $\mathrm{S} 2, \mathrm{M}_{\mathrm{B}}$. australiensis and $\mathrm{M}_{\mathrm{B}}$. maliensis belonged to $\mathrm{B}$ clade and are closer to each other than to any other moumouviruses, thus initiating a third sub-lineage. Interestingly, the B clade appeared the most divergent among mimiviruses.

\section{Zamilon vitis genome}

In addition, we determined the $17,454 \mathrm{bp}$ genome sequence $(30 \% \mathrm{G}+\mathrm{C})$ of Zamilon vitis. It was closely related to that of other virophages infecting the $\mathrm{B}$ and $\mathrm{C}$ clades, sharing 97.8\% identical nucleotides with the prototype Zamilon virophage [28]. The 20 predicted proteins were all conserved in other virophages infecting mimiviruses, sharing 40-80\% identical residues with Sputnik [25], their most distant homologue.

\section{The mvtv and matv transpovirons}

Finally, we determined the genome sequences of the two new transpovirons. The mvtv DNA sequence was $7417 \mathrm{bp}$ $(22 \% \mathrm{G}+\mathrm{C})$ in length and closely related to the one associated with Megavirus $_{\mathrm{C}}$ courdo7 $(98 \%$ identical nucleotides). The matv DNA sequence was $7584 \mathrm{bp}$ in length $(22 \% \mathrm{G}+\mathrm{C})$ and was related to the one associated with Moumouvirus $_{B}$ monve ( $89 \%$ identical nucleotides). The reconstructed phylogeny of all the known transpoviron genomes clearly showed that they fell into three distinct clusters, mirroring the tripartite clades structure of the host viruses from which they were isolated (Fig. 2).

Transpovirons exhibited terminal inverted repeats (TIRs) of $520 \mathrm{nt}$ for Mamavirus $\mathrm{A}_{\mathrm{A}}$ and Lentille virus $\mathrm{A}_{\mathrm{A}}$ transpovirons (lvtv), $380 \mathrm{nt}$ for matv and $510 \mathrm{nt}$ for mvtv. TIRs were missing from the transpovirons associated to Moumouvirus $_{\mathrm{B}}$ monve and Megavirus ${ }_{\mathrm{C}}$ courdo7, most likely because their published sequences are incomplete [26]. TIRs are well conserved within clades (90\% of identical nucleotides between Mamavirus ${ }_{\mathrm{A}}$ transpoviron and lvtv) but diverged between clades (56\% identical nucleotides between lvtv/ mvtv and 53\% between mvtv/matv). A tandem repeat (TR) of 180-600 nt was present in the centre of all sequenced transpovirons, in an intergenic region $3^{\prime}$ from a conserved helicase (Fig. 2). These TRs were also well conserved within clades (80\% identical nucleotides) and divergent between clades (39\% identical nucleotides). It is worth mentioning that an evolutionary link between virophages 


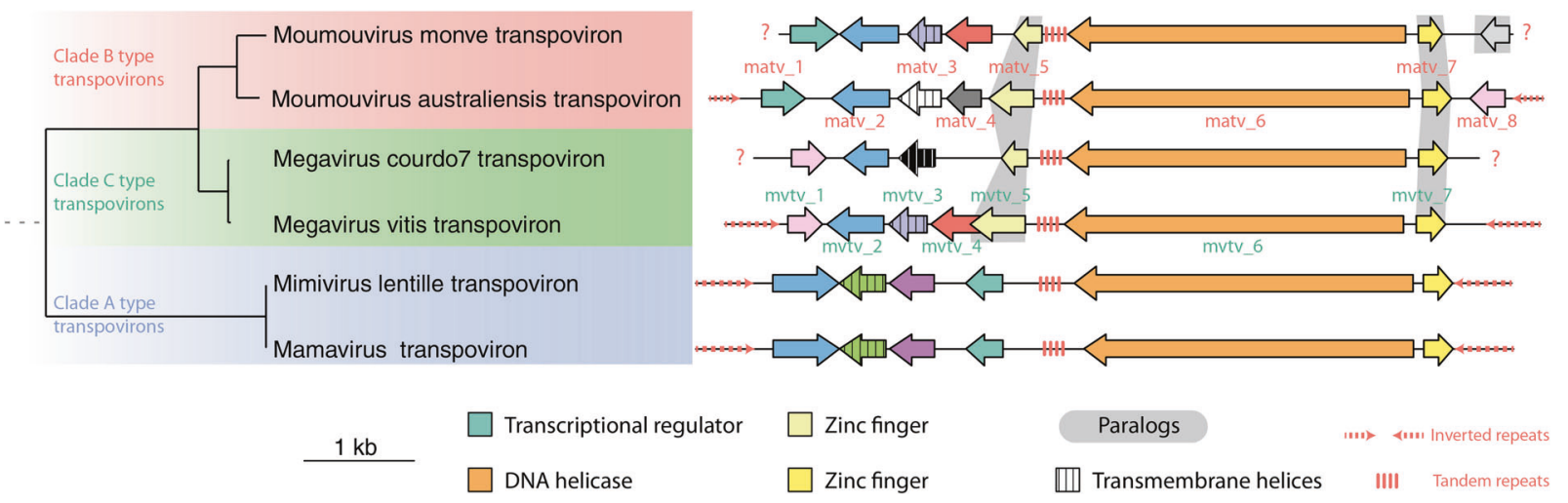

Fig. 2 Phylogeny and genomic organization of transpoviron sequences. The phylogenetic tree (on the left) was computed from the concatenated sequences of shared orthologous predicted proteins using PhyML [45] with the LG + G model. Bootstrap values (not shown) are

and transpovirons has been proposed [55]. Three predicted proteins were found in all transpovirons (i.e. core genes): a helicase (Mvtv_6/Matv_6), a protein of unknown function (Mvtv_2/Matv_2) and a zinc-finger domain-containing protein (Mvtv_7/Matv_7), (Fig. 2). In addition, all transpovirons encode a small protein with a central transmembrane segment as their only recognizable similarity (Mvtv_3/Matv_3). Seven predicted proteins were shared by at least two transpovirons, including a transcriptional regulator conserved in clades A and B (Matv_1), a protein paralogous to the above core zinc-finger-domain-containing protein and conserved in clades B and C (Mvtv_5/Matv_5), and five other predicted proteins without any functional signature. Finally, four proteins of unknown function were unique and had no detectable homologue in the other transpovirons.

We analyzed the proteome of $\mathrm{M}_{\mathrm{C}}$. vitis virions in search of transpoviron proteins specifically associated to this host virus. We identified three transpoviron proteins, Mvtv_3, a putative membrane protein that could be anchored in the giant virus membrane, and Mvtv_2 and Mvtv_4, two putative DNA-binding proteins (Fig. S6, Table S1).

Given that all known virophages infecting mimiviruses have been isolated in the presence of a transpoviron, we also expected the presence of transpoviron-encoded proteins in $\mathrm{Z}$. vitis virions. We thus analyzed the protein composition of the purified $Z$. vitis particles produced with $\mathrm{M}_{\mathrm{C}}$. vitis. The proteomic study confirmed this prediction but suggests a specific interaction between the transpoviron proteins and the virophage in one hand, and the transpoviron proteins and the host virus particles in the other hand. Indeed, in virophage particles, we consistently identified two transpoviron proteins, Mvtv_7, a putative DNAbinding protein and in lesser amount the predicted helicase Mvtv_6 never identified in the $M_{C}$ vitis particles in the absence of virophage particles (Table S1). Four additional all equal to one. The genomic organization (right) shows orthologous genes represented with identical colours and paralogous genes (in a given genome) are highlighted in grey. Gene names are indicated for matv and mvtv.

proteins were also detected but in much smaller amount, three predicted DNA-binding protein (Mvtv_5, Mvtv_2 and Mvtv_4 in decreasing amounts) and a protein with unknown function, Mvtv_1. These four proteins were also seen in the total proteome of the $\mathrm{M}_{\mathrm{C}}$. vitis $+\mathrm{Z}$. vitis virions. In contrast, they were all absent from the proteome of the cloned $\mathrm{M}_{\mathrm{C}}$. Vitis particles (Fig. S6). Thus, the transpoviron encodes different subsets of proteins that might be specifically involved in their packaging in two alternative vehicles: the virophage or the host virus particle.

\section{Clade specificity of transpovirons}

First, we verified that $Z$. vitis virophage replication was restricted to host viruses from the $\mathrm{B}$ and $\mathrm{C}$ clades, as previously described for Zamilon virophages (Table 1) [28]. We also verified by PCR that the $\mathrm{M}_{\mathrm{C}}$. vitis clone cleared from virophage and replicated on A. castellanii cells remained associated with its transpoviron mvtv.

Purified virophage virions carrying the mvtv transpoviron were then used to co-infect $A$. castellanii with two Cclade megaviruses $\left(\mathrm{M}_{\mathrm{C}}\right.$. vitis/mvtv and $\mathrm{M}_{\mathrm{C}}$. chilensis w/o transpoviron) and two B-clade moumouviruses $\left(\mathrm{M}_{\mathrm{B}}\right.$. australiensis/matv and $\mathrm{M}_{\mathrm{B}}$. maliensis w/o transpoviron) to assess whether the transpovirons were specific to a given clade of mimiviruses (Fig. 3a).

We performed specific PCR for each transpoviron after each round of co-infection and for each additional round of production (up to ten) to assess the presence of matv and mvtv DNA in the cultures after cell lysis. We also performed a proteomic analysis of the resulting virophages to assess the presence of transpoviron proteins (Table S1).

Co-infection of the virophage (carrying mvtv) with $\mathrm{M}_{\mathrm{B}}$. australiensis (carrying matv) surprisingly produced a unique population of neo-synthesized virophage particles carrying 
Table 1 Permissivity of the host Megavirinae to Z . vitis virophage and their selectivity for the transpovirons.

\begin{tabular}{|c|c|c|c|c|}
\hline \multirow[t]{2}{*}{ Clade } & \multirow[t]{2}{*}{ Giant virus } & \multirow[t]{2}{*}{ Permissivity to Z. vitis } & \multicolumn{2}{|c|}{ Selectivity for transpoviron } \\
\hline & & & Z. vitis + mvtv & Z. vitis + matv \\
\hline $\mathbf{A}$ & Mimivirus & - & mvtv- & matv- \\
\hline \multirow[t]{3}{*}{$\mathbf{C}$} & $\mathrm{M}_{\mathrm{C}}$. chilensis & + & mvtv + & matv + \\
\hline & $\mathbf{M}_{C} \cdot$ chilensis $+\mathbf{m v t v}$ & + & mvtv + & mvtv + matv + \\
\hline & $\mathrm{M}_{\mathrm{C}}$. chilensis + matv & + & matv + mvtv + & matv + \\
\hline $\mathbf{C}$ & $\mathrm{M}_{\mathrm{C}} \cdot$ vitis $+\underline{\text { mvtv }}$ & + & mvtv + & mvtv + \\
\hline B & $\mathrm{M}_{\mathrm{B}}$. australiensis $+\underline{\text { matv }}$ & + & matv + & matv + \\
\hline \multirow[t]{3}{*}{$\mathbf{B}$} & $\mathrm{M}_{\mathrm{B}}$. maliensis & + & $\operatorname{mvtv}+$ & matv + \\
\hline & $\mathrm{M}_{\mathrm{B}} \cdot$ maliensis + matv & + & matv + mvtv + & matv + \\
\hline & $\mathrm{M}_{\mathrm{B}} \cdot$ maliensis + mvtv & + & mvtv + & $\operatorname{mvtv}+$ matv + \\
\hline
\end{tabular}

Transpovirons originally associated to a given host virus are underlined. Most abundant transpovirons in host particles are shown in bold the matv transpovirons (Table 1, lane 6). The proteomic analysis of the purified virophage capsids also evidenced the replacement of the mvtv proteins by their orthologues in matv, matv_7 and matv_6 and to a lesser extend matv_2. In contrast the orthologues of Mvtv_1 (Matv_8) and Mvtv_5 (Matv_5) were not detected (Table S1). Moreover, PCR performed along the infection cycle of $\mathrm{M}_{\mathrm{B}}$. australiensis (carrying matv) and the virophage (carrying mvtv) did not show an increase in mvtv while the matv genome was clearly replicated (Fig. S3A). These results suggested that the host virus strongly favour the replication of its natively associated transpoviron (Table 1, Fig. 3b). If a different one is brought in by the virophage, it is lost and replaced by the one replicated by the host virus, a result we refer to as the "dominance effect". Consequently, two populations of virophages carrying either mvtv or matv were at our disposal. We confirmed the dominance effect by co-infection of $\mathrm{M}_{\mathrm{C}}$. vitis carrying mvtv with virophages carrying matv (Table 1, lane 5). Again, we observed the replacement in the virophage particles of matv (DNA and proteins) by mvtv (DNA and proteins). We also confirmed that the mvtv genome was actively replicated while the amount of matv genome remained stable along the infectious cycle (Fig. S3B). We then used the virophages carrying either mvtv or matv to infect transpoviron-free B-clade $\left(\mathrm{M}_{\mathrm{B}}\right.$. maliensis) and $\mathrm{C}$-clade $\left(\mathrm{M}_{\mathrm{C}}\right.$. chilensis) host viruses. We found that the virophage succeeded in transmitting each transpoviron to each "empty" B- or C-clade host viruses (Table 1, lanes 2 and 7), a result we refer to as the "permissive effect". However, we observed that matv was preferentially replicated by $M_{B}$. maliensis and mvtv by $M_{C}$. chilensis (Table 1). By cloning we showed that the resulting populations of B- and C-clade host viruses were mixtures of transpoviron positive and transpoviron negative particles (Fig. S7). Furthermore, virophage particles produced by transpoviron negatives clones were also devoid of transpoviron (DNA and proteins), indicating that although transpovirons can be carried by virophages, their replication is performed and controlled by the host virus.

We finally took advantage of the permissive effect to produce two populations of clade $\mathrm{B}\left(\mathrm{M}_{\mathrm{B}}\right.$. maliensis) and $\mathrm{C}$ $\left(\mathrm{M}_{\mathrm{C}}\right.$. chilensis) host viruses, each carrying the matv or mvtv transpoviron. We then challenged them using virophages carrying the other transpoviron. We performed PCR specific for either transpoviron after each round of virophage coinfection (up to ten successive rounds of virophage production) and assessed their presence after cell lysis.

The proteome of the virophages particles was also analysed in order to assess the presence of transpoviron proteins possibly associated to the transpoviron DNA. The results of the various experiments are presented in Table 1 and Table S1 and are interpreted in Fig. 3.

When we infected populations of $\mathrm{M}_{\mathrm{C}}$. chilensis carrying matv or mvtv with virophages carrying the complementary transpoviron, the resulting population of $\mathrm{M}_{\mathrm{C}}$. chilensis and virophages became positive for the two transpovirons (Table 1, lanes 3 and 4). This apparently violated the strict "dominance effect" observed with $\mathrm{M}_{\mathrm{C}}$. vitis and $\mathrm{M}_{\mathrm{B}}$. australiensis. However, the persistence of a subpopulation of empty $M_{C}$. chilensis virion (i.e. devoid of transpoviron) might also explain our results without refuting the dominance rule. In that case, the replication and propagation of the competing virophage-borne transpoviron would be performed by the transpoviron-null (empty) $\mathrm{M}_{\mathrm{C}}$. chilensis subpopulation. We investigated this possibility by cloning virions from the mixed mvtv/matv $\mathrm{M}_{\mathrm{C}}$. chilensis population and examining their transpoviron content. Strikingly, we never observed $\mathrm{M}_{\mathrm{C}}$. chilensis virions simultaneously carrying both types of transpovirons. On the other hand, we observed either mvtv positive (mvtv+) or matv positive $\left(\right.$ matv + ) $\mathrm{M}_{\mathrm{C}}$. chilensis clones, as well as others devoid of transpovirons (Fig. 3). This result also suggests that the association between the host virus and the transpovirons are not stable when resulting from a first encounter. In the case 
A

$\begin{gathered}\text { Moumouviruss } \\ \text { maliensis } \\ \text { australensis } \\ \text { matv+ }\end{gathered}$
$\begin{gathered}\text { mvtv+ } \\ \text { chilensis }\end{gathered}$

B
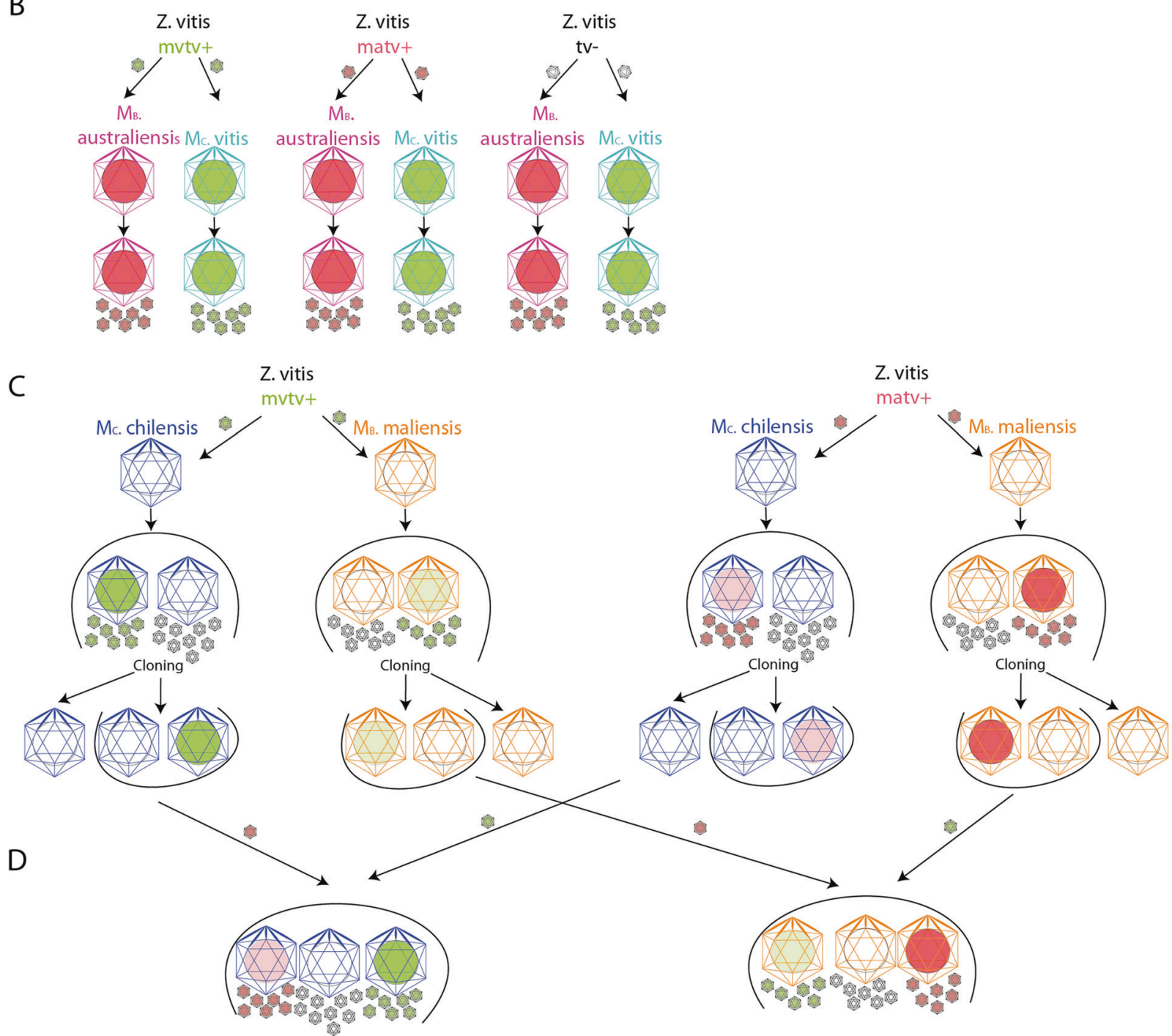

Fig. 3 Dominance effect versus permissive effect. a Viruses used in this study. $M_{B}$. maliensis is represented in orange, $M_{B}$. australiensis in purple, $\mathbf{M}_{C}$. vitis in cyan and $\mathrm{M}_{\mathrm{C}}$. chilensis in dark blue. The transpovirons are represented as coloured circles (green for mvtv and pink for matv) inside the giant virus and virophage capsids. b Dominance effect of the resident transpoviron (mvtv in $\mathrm{M}_{\mathrm{C}}$. vitis, green circle in cyan capsid; matv in $M_{B}$. australiensis, pink circle in purple capsid) over the one carried by Z. vitis. Empty Z. vitis (black contour, white

capsid) do acquire the resident transpoviron upon replication; c Permissive effect: the two type of transpovirons can be imported and replicated by empty $\mathrm{M}_{\mathrm{C}}$. chilensis (dark blue capsid, white circle) and $\mathrm{M}_{\mathrm{B}}$. maliensis (orange capsids, white circle), although with different efficiencies. d Combination of the dominance and permissive effect. Colour intensities of the circles (pink for matv, green for mvtv) illustrate the abundance of the transpovirons in the host and virophage particles.

of $\mathrm{M}_{\mathrm{B}}$. maliensis in the presence of virophage matv, the replacement of the mvtv transpoviron from host particles appeared to be faster, which resulted in the rapid disappearance of mvtv after only six rounds of replication. We also observed that the loss of the transpoviron over host virus replication, in the absence of virophage, was more rapid for $\mathrm{M}_{\mathrm{B}}$. maliensis than $\mathrm{M}_{\mathrm{C}}$. chilensis suggesting the association between the host virus and the transpoviron was not stable. The cloning step provided virophage-free host virus clones with which to replicate these competition 
experiments: the matv + or mvtv + clones infected by virophages carrying the complementary transpoviron again produced a mixed population of matv,$+ \operatorname{mvtv}+$ and transpoviron-null virions (Table 1, lanes 8 and 9). Thus, the persistence of particles devoid of transpoviron allows us to conclude that our results are a combination of the "dominance effect" applied to the subpopulation of transpoviron positive virions and of the "permissive effect" applied to the transpoviron-null subpopulation. In the resulting virophage particles, the only transpoviron proteins consistently identified were Mvtv_7/Matv_7 and Mvtv_6/Matv_6. As expected, they were absent from virophages devoid of transpoviron (Table S1).

To elucidate whether the transpoviron could have a protective role against infection of the host virus by the virophage, we compared the infectious cycles of Acanthamoeba cells infected by $\mathrm{M}_{\mathrm{C}}$. chilensis carrying matv, mvtv or without transpoviron. They were strikingly similar both in terms of cycle length and virus production yields. Transpovirons are thus not key, at least in laboratory conditions, in regulating the permissivity of mimiviruses to virophage infection.

\section{Discussion}

Mimiviruses are unique in their association with two distinct (often co-existing) dependent entities, virophages and transpovirons, somewhat reminiscent of phages and plasmids afflicting bacteria. As for the virophage, the presence of host virus-like regulatory elements (terminator hairpin and late promoter [56-59]) flanking the transpoviron genes suggest that they also use the host virus transcription machinery rather than that of the cell. The transpoviron might also rely on the host virus DNA replication machinery, in absence of transpoviron-encoded DNA polymerase. Our competition experiments between the mvtv $v s$. matv transpovirons resulted in the replication of only one transpoviron. Interestingly, the "winner" corresponds to the type originally associated to the host virus (mvtv for $\mathrm{M}_{\mathrm{C}}$. vitis and matv for $\mathrm{M}_{\mathrm{B}}$. australiensis, Table 1), a phenomenon we called the "dominance effect". This finding was also confirmed by the immediate replacement of mvtv by matv proteins in virophage particles synthetized with $\mathrm{M}_{\mathrm{B}}$. australiensis. However, this result is not simply due to a strict clade-wise specificity. The use of transpoviron-free host virus particles allowed us to demonstrate that $\mathrm{M}_{\mathrm{C}}$. chilensis and $\mathrm{M}_{\mathrm{B}}$. maliensis can replicate and incorporate each transpoviron, independently (Table 1). Yet, we observed a marked difference in permissivity, with B- and $\mathrm{C}$-clade host viruses favouring their cognate transpoviron types. The central TRs sequences and the TIR flanking the transpovirons replicated by A-clade vs. B- or C-clade host viruses are markedly different. These differences might cause the lack of replication of matv and mvtv in the A-clade Mimivirus. The lesser differences between the B- and C-clade transpovirons might then explain why both of them can still be replicated by $\mathrm{M}_{\mathrm{B}}$. maliensis and $\mathrm{M}_{\mathrm{C}}$. chilensis. In these host viruses, the competition experiment resulted in the simultaneous replication of both transpovirons. However, the sub-cloning of the mvtv $+/$ matv + population resulted in mvtv + only, matv + only, or transpoviron negative clones. It also appears that neither of the two transpovirons remains stably associated with a host virus for which it was a first encounter, while a preference could emerge once a stable association has been established by co-evolution (i.e. $\mathrm{M}_{\mathrm{B}}$. australiensis with matv, $\mathrm{M}_{\mathrm{C}}$. vitis with mvtv). Finally, in virophage particles there were fewer copies of matv either produced with $\mathrm{M}_{\mathrm{B}}$. australiensis, $\mathrm{M}_{\mathrm{B}}$. maliensis or $\mathrm{M}_{\mathrm{C}}$. chilensis and fewer copies of mvtv produced with $\mathrm{M}_{\mathrm{C}}$. chilensis or $\mathrm{M}_{\mathrm{B}}$. maliensis, compared with the number of copies of mvtv produced with $\mathrm{M}_{\mathrm{C}}$. vitis. Different transpovirons, even efficiently replicated by the host virus, thus appear to be loaded at different efficiencies in the virophage particles (Fig. S8). A similar result was previously described for the Lentille virus transpoviron that could only be detected in Sputnik2 virophage particles using FISH experiments [26]. A consequence of such suboptimal associations was the production of virophages devoid of transpovirons that could then be used to identify candidate proteins involved in the transpoviron/virophage association. The only difference between virophage particles carrying or not transpovirons was the recurrent presence of two transpoviron-encoded proteins (Mvtv_7/Matv_7 and Mvtv_6/ Matv_6) together with the DNA molecule as an episome (Table S1, Fig. S8) suggesting the virophage was a mere vehicle for the transpoviron. These proteins are conserved in all transpovirons, are predicted to be DNA-binding, and were not identified in the proteome of the host virus. Instead, the most abundant transpoviron proteins in $\mathrm{M}_{\mathrm{C}}$. vitis virions were two predicted DNA-binding proteins (Mvtv_2 and Mvtv_4) and one predicted membrane protein (Mvtv_3) that could be anchored in the host virus membrane (Table S1). All transpovirons encode a short predicted membrane protein although their primary sequence does appear to be conserved. The dominance effect is reminiscent of plasmids incompatibility or entry exclusion for related plasmids [60-63] or superinfection immunity [64] and superinfection exclusion [65] used by prophages to prevent superinfection by other bacteriophages. For the latter, DNA injection is often inhibited by a membrane-bound protein [66-68], paralleling the eventual role of the transpoviron-encoded membrane protein in giant virus particles carrying a transpoviron.

Since the transpoviron genome is present in both the host virus and the virophage particles, the transpoviron DNA might also adopt a different organization depending on the vehicle (host virus or virophage particles) used for its propagation. The Mvtv_7/Matv_7 and Mvtv_6/Matv_6 
proteins could be involved in the packaging or delivery of the transpoviron in and from the virophage particle, while the Mvtv_2/Matv_2 and Mvtv_4 proteins could play a similar role vis-à-vis the host virus and the Mvtv_3 membrane protein may play a role in the dominance effect. Further studies are needed to elucidate the mechanisms at work in packaging and delivery of transpoviron genomes as well as in transpoviron dominance.

The first two types of virophage that have been discovered, Sputnik and Mavirus, respectively infecting Mimivirus [25] and Cafeteria roenbergensis [31] are strongly deleterious to their host viruses, diminishing the production of infectious particles [25, 26, 69] or stopping it altogether [31, 32], effectively protecting the cellular hosts. As parasite of another parasite (the giant virus), these virophages are bona fide hyperparasites [70, 71]. The detection of many additional virophage-related sequences in aquatic environment together with that of Mimivirus-like viruses suggested that they might have a significant ecological role in regulating the population of the giant viruses and of their cellular host (micro-algae or heterotrophic protozoans) [72-74]. However, the hypovirulence (of the host virus) induced by the hyperparasite may ultimately limit its own reproductive success [70]. Thus the evolutionary trajectory of the virophage/host virus/cellular host parasitic cascade may remain antagonistic or end up in a mutualistic or commensal relationship. The uniquely complex tripartite parasitic cascade transpoviron/virophage/host virus analyzed in this work, where none of the actors appears to have a detrimental effect on the others, at least in laboratory conditions, might be at a neutral equilibrium reached as a stable compromise after eons of intricate antagonistic evolution. To the best of our knowledge, the relationship between the transpoviron, the Zamilon virophage and their host giant virus analysed in this work represents the first example of bipartite commensalism in the viral world.

\section{Data availability}

The annotated genomic sequences determined for this work have been deposited in the Genbank/EMBL/DDBJ database under the following accession numbers: $M$. vitis: MG807319, M. australiensis: MG807320, M. maliensis: MK978772, Z. vitis: MG807318, mvtv: MG807316 and matv, MG807317. The mass spectrometry proteomics data have been deposited to the ProteomeXchange Consortium via the PRIDE partner repository with the dataset identifier PXD009037 [75].

Acknowledgements This work was partially supported by the French National Research Agency ANR-14-CE14-0023-01, Institut Français de Bioinformatique (ANR-11-INSB-0013), the Fondation Bettencourt Schueller (OTP51251) and the Provence-Alpes-Côte-d'Azur région (2010 12125). Proteomic experiments were partly supported by the ProFi grant (ANR-10-INBS-08-01). We thank Laurence De
Marchi and Daouda Traore for providing the soil samples and Olivier Poirot for helpful discussions. We thank Dr Elsa Garcin for reading and improving the manuscript. We also thank Dr A. Kosta at the IMM imagery platform and F. Richard and A. Aouane for their expert assistance on the IBDM imaging platform and Dr N. Brouilly for data acquisition that allowed producing the Supplementary movie. We also acknowledge the support of the bottom-up platform and informatics group of EDyP.

\section{Compliance with ethical standards}

Conflict of interest The authors declare that they have no conflict of interest.

Publisher's note Springer Nature remains neutral with regard to jurisdictional claims in published maps and institutional affiliations.

Open Access This article is licensed under a Creative Commons Attribution 4.0 International License, which permits use, sharing, adaptation, distribution and reproduction in any medium or format, as long as you give appropriate credit to the original author(s) and the source, provide a link to the Creative Commons license, and indicate if changes were made. The images or other third party material in this article are included in the article's Creative Commons license, unless indicated otherwise in a credit line to the material. If material is not included in the article's Creative Commons license and your intended use is not permitted by statutory regulation or exceeds the permitted use, you will need to obtain permission directly from the copyright holder. To view a copy of this license, visit http://creativecommons. org/licenses/by/4.0/.

\section{References}

1. Wommack KE, Colwell RR. Virioplankton: viruses in aquatic ecosystems. Microbiol Mol Biol Rev. 2000;64:69-114.

2. Suttle CA. Marine viruses-major players in the global ecosystem. Nat Rev Microbiol. 2007;5:801-12.

3. Rowe JM, DeBruyn JM, Poorvin L, LeCleir GR, Johnson ZI, Zinser ER, et al. Viral and bacterial abundance and production in the Western Pacific Ocean and the relation to other oceanic realms. FEMS Microbiol Ecol. 2012;79:359-70.

4. Wigington $\mathrm{CH}$, Sonderegger D, Brussaard CPD, Buchan A, Finke JF, Fuhrman JA, et al. Re-examination of the relationship between marine virus and microbial cell abundances. Nat Microbiol. 2016; $1: 15024$.

5. Schulz F, Alteio L, Goudeau D, Ryan EM, Yu FB, Malmstrom $\mathrm{RR}$, et al. Hidden diversity of soil giant viruses. Nat Commun. 2018;9:4881.

6. Abeles SR, Pride DT. Molecular bases and role of viruses in the human microbiome. J Mol Biol. 2014;426:3892-906.

7. Barr JJ. A bacteriophages journey through the human body. Immunol Rev. 2017;279:106-22.

8. Atoni E, Wang Y, Karungu S, Waruhiu C, Zohaib A, Obanda V, et al. Metagenomic virome analysis of culex mosquitoes from Kenya and China. Viruses. 2018;10:30.

9. Scola BL, Audic S, Robert C, Jungang L, Lamballerie X, de, Drancourt M. et al. A giant virus in amoebae. Science. 2003; 299:2033.

10. Raoult D, Audic S, Robert C, Abergel C, Renesto P, Ogata H, et al. The 1.2-megabase genome sequence of Mimivirus. Science. 2004;306:1344-50.

11. Philippe N, Legendre M, Doutre G, Coute Y, Poirot O, Lescot M, et al. Pandoraviruses: amoeba viruses with genomes up to $2.5 \mathrm{Mb}$ reaching that of parasitic eukaryotes. Science. 2013;341:281-6. 
12. Legendre M, Lartigue A, Bertaux L, Jeudy S, Bartoli J, Lescot M, et al. In-depth study of Mollivirus sibericum, a new 30,000-y-old giant virus infecting Acanthamoeba. Proc Natl Acad Sci USA. 2015;112:E5327-35.

13. Legendre M, Bartoli J, Shmakova L, Jeudy S, Labadie K, Adrait A, et al. Thirty-thousand-year-old distant relative of giant icosahedral DNA viruses with a pandoravirus morphology. Proc Natl Acad Sci USA. 2014;111:4274-9.

14. Wilson WH, Schroeder DC, Allen MJ, Holden MTG, Parkhill J, Barrell BG, et al. Complete genome sequence and lytic phase transcription profile of a Coccolithovirus. Science. 2005;309:1090-2.

15. Fischer MG, Allen MJ, Wilson WH, Suttle CA. Giant virus with a remarkable complement of genes infects marine zooplankton. Proc Natl Acad Sci USA. 2010;107:19508-13.

16. Santini S, Jeudy S, Bartoli J, Poirot O, Lescot M, Abergel C, et al. Genome of Phaeocystis globosa virus PgV-16T highlights the common ancestry of the largest known DNA viruses infecting eukaryotes. Proc Natl Acad Sci USA. 2013;110:10800-5.

17. Gallot-Lavallée L, Blanc G, Claverie J-M. Comparative genomics of Chrysochromulina ericina virus and other microalga-infecting large DNA viruses highlights their intricate evolutionary relationship with the established Mimiviridae family. J Virol. 2017; 91:e00230-17.

18. Deeg CM, Chow C-ET, Suttle CA. The kinetoplastid-infecting Bodo saltans virus (BsV), a window into the most abundant giant viruses in the sea. 2017;7: e33014. https://doi.org/10.7554/eLife. 33014.

19. Sheyn U, Rosenwasser S, Lehahn Y, Barak-Gavish N, Rotkopf R, Bidle KD, et al. Expression profiling of host and virus during a coccolithophore bloom provides insights into the role of viral infection in promoting carbon export. ISME J. 2018;12:704-13.

20. Arslan D, Legendre M, Seltzer V, Abergel C, Claverie J-M. Distant Mimivirus relative with a larger genome highlights the fundamental features of Megaviridae. Proc Natl Acad Sci USA. 2011;108:17486-91.

21. Yoosuf N, Yutin N, Colson P, Shabalina SA, Pagnier I, Robert C, et al. Related giant viruses in distant locations and different habitats: Acanthamoeba polyphaga moumouvirus represents a third lineage of the Mimiviridae that is close to the megavirus lineage. Genome Biol Evol. 2012;4:1324-30.

22. Yoosuf N, Pagnier I, Fournous G, Robert C, La Scola B, Raoult $\mathrm{D}$, et al. Complete genome sequence of Courdo11 virus, a member of the family Mimiviridae. Virus Genes. 2014;48:218-23.

23. Claverie J-M, Abergel C. Mimiviridae: an expanding family of highly diverse large dsDNA viruses infecting a wide phylogenetic range of aquatic eukaryotes. Viruses. 2018;10:E506.

24. Schulz F, Yutin N, Ivanova NN, Ortega DR, Lee TK, Vierheilig J, et al. Giant viruses with an expanded complement of translation system components. Science. 2017;356:82-5.

25. La Scola B, Desnues C, Pagnier I, Robert C, Barrassi L, Fournous $\mathrm{G}$, et al. The virophage as a unique parasite of the giant Mimivirus. Nature. 2008;455:100-4.

26. Desnues C, La Scola B, Yutin N, Fournous G, Robert C, Azza S, et al. Provirophages and transpovirons as the diverse mobilome of giant viruses. Proc Natl Acad Sci USA. 2012;109:18078-83.

27. Gaia M, Pagnier I, Campocasso A, Fournous G, Raoult D, La Scola B. Broad spectrum of mimiviridae virophage allows its isolation using a Mimivirus reporter. PloS ONE. 2013;8:e61912.

28. Gaia M, Benamar S, Boughalmi M, Pagnier I, Croce O, Colson P, et al. Zamilon, a novel virophage with Mimiviridae host specificity. PloS ONE. 2014;9:e94923.

29. Krupovic M, Kuhn JH, Fischer MG. A classification system for virophages and satellite viruses. Arch Virol. 2016;161:233-47.

30. Bekliz M, Colson P, La Scola B. The expanding family of virophages. Viruses. 2016;8: E317. https://doi.org/10.3390/ v8110317.
31. Fischer MG, Suttle CA. A virophage at the origin of large DNA transposons. Science. 2011;332:231-4.

32. Fischer MG, Hackl T. Host genome integration and giant virusinduced reactivation of the virophage mavirus. Nature. 2016; 540:288-91.

33. Levasseur A, Bekliz M, Chabrière E, Pontarotti P, La Scola B, Raoult D. MIMIVIRE is a defence system in Mimivirus that confers resistance to virophage. Nature. 2016;531:249-52.

34. Claverie J-M, Abergel C. CRISPR-Cas-like system in giant viruses: why MIMIVIRE is not likely to be an adaptive immune system. Virol Sin. 2016;31:193-6.

35. Mougari S, Abrahao J, Oliveira GP, Bou Khalil JY, La Scola B. Role of the R349 gene and its repeats in the MIMIVIRE defense system. Front Microbiol. 2019;10:1147.

36. Fabre E, Jeudy S, Santini S, Legendre M, Trauchessec M, Couté $\mathrm{Y}$, et al. Noumeavirus replication relies on a transient remote control of the host nucleus. Nat Commun. 2017;8:15087.

37. Chin C-S, Alexander DH, Marks P, Klammer AA, Drake J, Heiner $\mathrm{C}$, et al. Nonhybrid, finished microbial genome assemblies from long-read SMRT sequencing data. Nat Methods. 2013;10:563-9.

38. Nurk S, Bankevich A, Antipov D, Gurevich A, Korobeynikov A, Lapidus A, et al. Assembling single-cell genomes and minimetagenomes from chimeric MDA products. J Comput Biol. 2013;20:714-37.

39. Stanke M, Waack S. Gene prediction with a hidden Markov model and a new intron submodel. Bioinformatics. 2003;19 (Suppl_2): ii215-25.

40. Lowe TM, Eddy SR. tRNAscan-SE: a program for improved detection of transfer RNA genes in genomic sequence. Nucleic Acids Res. 1997;25:955-64.

41. Altschul SF, Gish W, Miller W, Myers EW, Lipman DJ. Basic local alignment search tool. J Mol Biol. 1990;215:403-10.

42. Marchler-Bauer A, Bo Y, Han L, He J, Lanczycki CJ, Lu S, et al. CDD/SPARCLE: functional classification of proteins via subfamily domain architectures. Nucleic Acids Res. 2017;45: D200-3.

43. Darriba D, Taboada GL, Doallo R, Posada D. ProtTest 3: fast selection of best-fit models of protein evolution. Bioinforma Oxf Engl. 2011;27:1164-5.

44. Enright AJ, Van Dongen S, Ouzounis CA. An efficient algorithm for large-scale detection of protein families. Nucleic Acids Res. 2002;30:1575-84.

45. Wallace IM, O’Sullivan O, Higgins DG, Notredame C. M-Coffee: combining multiple sequence alignment methods with T-Coffee. Nucleic Acids Res. 2006;34:1692-9.

46. Yoon S-H, Ha S-M, Lim J, Kwon S, Chun J. A large-scale evaluation of algorithms to calculate average nucleotide identity. Antonie Van Leeuwenhoek. 2017;110:1281-6.

47. Cox J, Mann M. MaxQuant enables high peptide identification rates, individualized p.p.b.-range mass accuracies and proteomewide protein quantification. Nat Biotechnol. 2008;26:1367-72.

48. Schwanhäusser B, Busse D, Li N, Dittmar G, Schuchhardt J, Wolf $\mathrm{J}$, et al. Global quantification of mammalian gene expression control. Nature. 2011;473:337-42.

49. Shin J-B, Krey JF, Hassan A, Metlagel Z, Tauscher AN, Pagana $\mathrm{JM}$, et al. Molecular architecture of the chick vestibular hair bundle. Nat Neurosci. 2013;16:365-74.

50. Zauberman N, Mutsafi Y, Halevy DB, Shimoni E, Klein E, Xiao $\mathrm{C}$, et al. Distinct DNA exit and packaging portals in the virus Acanthamoeba polyphaga Mimivirus. PLoS Biol. 2008;6:e114.

51. Abrahão J, Silva L, Silva LS, Khalil JYB, Rodrigues R, Arantes T, et al. Tailed giant Tupanvirus possesses the most complete translational apparatus of the known virosphere. Nat Commun. 2018;9:749.

52. Andrade ACDSP, Rodrigues RAL, Oliveira GP, Andrade KR, Bonjardim CA, La Scola B, et al. Filling knowledge gaps for 
Mimivirus entry, uncoating, and morphogenesis. J Virol. 2017;91: e01335-17.

53. Claverie J-M, Abergel C. Mimivirus and its virophage. Annu Rev Genet. 2009;43:49-66.

54. Yoosuf N, Pagnier I, Fournous G, Robert C, Raoult D, La Scola $\mathrm{B}$, et al. Draft genome sequences of Terra1 and Terra2 viruses, new members of the family Mimiviridae isolated from soil. Virology. 2014;452-453:125-32.

55. Krupovic M, Yutin N, Koonin EV. Fusion of a superfamily 1 helicase and an inactivated DNA polymerase is a signature of common evolutionary history of Polintons, polinton-like viruses, Tr1 transposons and transpovirons. Virus Evol. 2016;2:vew019.

56. Byrne D, Grzela R, Lartigue A, Audic S, Chenivesse S, Encinas S, et al. The polyadenylation site of Mimivirus transcripts obeys a stringent "hairpin rule". Genome Res. 2009;19:1233-42.

57. Legendre M, Audic S, Poirot O, Hingamp P, Seltzer V, Byrne D, et al. mRNA deep sequencing reveals 75 new genes and a complex transcriptional landscape in Mimivirus. Genome Res. 2010; 20:664-74.

58. Legendre M, Santini S, Rico A, Abergel C, Claverie J-M. Breaking the 1000-gene barrier for Mimivirus using ultra-deep genome and transcriptome sequencing. Virol J. 2011;8:99.

59. Priet S, Lartigue A, Debart F, Claverie J-M, Abergel C. mRNA maturation in giant viruses: variation on a theme. Nucleic Acids Res. 2015;43:3776-88.

60. Novick RP. Extrachromosomal inheritance in bacteria. Bacteriol Rev. 1969;33:210-63.

61. Novick RP. Plasmid incompatibility. Microbiol Rev. 1987;51: 381-95.

62. Garcillán-Barcia MP, de la Cruz F. Why is entry exclusion an essential feature of conjugative plasmids? Plasmid. 2008;60:1-18.

63. Humbert M, Huguet KT, Coulombe F, Burrus V. Entry exclusion of conjugative plasmids of the IncA, IncC and related untyped incompatibility groups. J Bacteriol. 2019;201:e00731-18.

64. Donnelly-Wu MK, Jacobs WR, Hatfull GF. Superinfection immunity of mycobacteriophage L5: applications for genetic transformation of mycobacteria. Mol Microbiol. 1993;7:407-17.
65. Susskind MM, Wright A, Botstein D. Superinfection exclusion by P22 prophage in lysogens of Salmonella typhimurium. IV. Genetics and physiology of sieB exclusion. Virology. 1974;62: 367-84.

66. McGrath S, Fitzgerald GF, van Sinderen D. Identification and characterization of phage-resistance genes in temperate lactococcal bacteriophages. Mol Microbiol. 2002;43:509-20.

67. Mahony J, McGrath S, Fitzgerald GF, van Sinderen D. Identification and characterization of lactococcal-prophage-carried superinfection exclusion genes. Appl Environ Microbiol. 2008;74: 6206-15.

68. Sun X, Göhler A, Heller KJ, Neve H. The ltp gene of temperate Streptococcus thermophilus phage TP-J34 confers superinfection exclusion to Streptococcus thermophilus and Lactococcus lactis. Virology. 2006;350:146-57.

69. Borges IA, de AssisFL, LKDS Silva, Abrahão J. Rio Negro virophage: sequencing of the near complete genome and transmission electron microscopy of viral factories and particles. Braz J Microbiol Publ Braz Soc Microbiol. 2018;49 (Suppl 1):260-1.

70. Parratt SR, Laine A-L. The role of hyperparasitism in microbial pathogen ecology and evolution. ISME J. 2016;10:1815-22.

71. Duponchel S, Fischer MG. Viva lavidaviruses! Five features of virophages that parasitize giant DNA viruses. PLoS Pathog. 2019;15:e1007592.

72. Yau S, Lauro FM, DeMaere MZ, Brown MV, Thomas T, Raftery MJ, et al. Virophage control of antarctic algal host-virus dynamics. Proc Natl Acad Sci USA. 2011;108:6163-8.

73. Wilkins D, Yau S, Williams TJ, Allen MA, Brown MV, DeMaere $\mathrm{MZ}$, et al. Key microbial drivers in Antarctic aquatic environments. FEMS Microbiol Rev. 2013;37:303-35.

74. Zhou J, Sun D, Childers A, McDermott TR, Wang Y, Liles MR. Three novel virophage genomes discovered from Yellowstone Lake metagenomes. J Virol. 2015;89:1278-85.

75. Vizcaíno JA, Csordas A, Del-Toro N, Dianes JA, Griss J, Lavidas I, et al. 2016 update of the PRIDE database and its related tools. Nucleic Acids Res. 2016;44:11033. 